\title{
Indigenous Crops of Asia and Southeast Asia: Exploring Health-promoting Properties
}

\author{
Bhimanagouda S. Patil', G.K. Jayaprakasha, and Amit Vikram \\ Vegetable and Fruit Improvement Center, Department of Horticultural Sciences, Texas A\&M University, 1500 \\ Research Parkway, Suite A120, College Station, TX 77843-2119
}

Additional index words. indigenous vegetables, phytochemicals, carotenoids, human health

\begin{abstract}
Diets rich in vegetables and fruits are known to be protective against several diseases. Only a limited number of vegetables and fruits are consumed as part of the daily diet in Western countries. Historically, indigenous vegetables and fruits are known for their medicinal and nutritional value in countries where they were originated and/or domesticated. However, relatively few systemic studies and reviews were conducted to enumerate the potential of these vegetables to human health benefits. Although certain indigenous crops have received attention, the majority of these crops with strong potential biological activities were neglected and/or not reported. Considering the current health-related problems and obesity-related diseases, it is timely to enumerate the health-promoting properties of certain indigenous vegetables. In this report, we have reviewed some of the important crops indigenous to Southeast Asia and their potential health-promoting properties.
\end{abstract}

Approximately 250,000 flowering species of plants are known and $\approx 50,000$ of these species are edible. Although humankind has used $\approx 3000$ plant species for food (Vietmeyer, 1986), only 11 crops (wheat, rice, corn, barley, sorghum/millet, potato, sweetpotato/yam, sugarcane, and soybean) contribute $\approx 75 \%$ of human food (Prohens et al., 2003). It is now well established that diets rich in fruits and vegetables (FAV) may have protective effects against cardiovascular disease and certain forms of cancer. These protective effects are attributed to bioactive compounds such as carotenoids, flavonoids, and other phenylpropanoids, which are present in FAV. Recently, health-maintaining properties of some of the bioactive compounds were reviewed (Patil et al., 2009). Indigenous vegetables have long been a vital component of the traditional diet in Asian and African countries. In contrast, food habits in the European and American countries are centered on meat, poultry, and dairy products. Although the Western diet is rich in protein, including certain amino acids and vitamins, which are present in lower concentrations in FAV, the Western diet seems to be deficient in certain bioactive compounds present only in certain indigenous vegetables and fruits. In comparison, a plant-based diet provides the essential nutrients as well as other bioactive compounds. Although these bioactive compounds and/or phytochemicals do not qualify as essential nutrients, they are increasingly being recognized for their potential health-maintaining properties. In general, consumption of FAV may account for the lower incidence of various chronic diseases. Several of the indigenous vegetables, including bitter melon, fenugreek, and Moringa

\footnotetext{
Received for publication 14 Dec. 2011. Accepted for publication 12 Mar. 2012.

This paper was part of the workshop "Asia's Indigenous Horticultural Crops" held 26 July 2009 at the ASHS Conference, St. Louis, MO, and sponsored by the Working Group of Asian Horticulture (WGAH).

${ }^{1}$ To whom reprint requests should be addressed; e-mail b-patil@tamu.edu.
}

oleifera Lam., are currently being studied for their health-promoting properties. Interestingly, recent studies seem to provide contradicting results of role of FAV in cancer prevention (Pierce et al., 2007; van Gils et al., 2005), which adds more confusion for consumers. There is an apparent need to study such potential crops to determine their effectiveness. This review discusses the health beneficial properties and bioactives of selected crops indigenous to Asia and Southeast Asia.

\section{BITTER GOURD (BITTER MELON)}

Bitter gourd (Momordica charantia L.) is cultivated throughout the world as a vegetable crop and considered to have potential benefits in reducing risk of diabetes (Grover and Yadav, 2004). Bitter gourd is intensively studied for its antidiabetic properties and several studies have reported potential biological properties such as hypoglycemic (Sarkar et al., 1996) and antihyperglycemic (Ahmed et al., 2004) activity from different plant parts such as fruit pulp, seed, leaves, and whole plant. Oral intake of freeze-dried bitter gourd juice reportedly reduced weight gain and body fat without affecting energy intake in high-fat-fed rats (Chen et al., 2003). The observed effects may possibly be attributed to reduced fat absorption, lowered serum insulin, and improvement in glucose tolerance. Furthermore, clinical trials (Table 1) using pulp and juice extracts of bitter gourd were reported to reduce blood glucose levels and improve glucose tolerance (Ahmad et al., 1999; Baldwa et al., 1977). The postulated mechanisms of bitter gourd hypoglycemic activity involve 1) modulation of xenobiotic metabolism by improving the activity of glutathione and glutathione Stransferase (Raza et al., 2000); 2) stimulation of insulin secretion by $\beta$-cells in obesehyperglycemic (Welihinda et al., 1982); and 3) activation of peroxidase proliferator-activated receptor (PPAR) (Che-Yi and Ching-jang, 2003). In addition, crude extracts from bitter gourd and purified fractions were documented to inhibit the growth of a number of human cancer cell lines (Grover and Yadav,
2004; Kobori, 2003). PPAR plays a role in lipid and glucose homeostasis, cellular differentiation, apoptosis, and cancer development as well as controlling the inflammatory response (Kersten et al., 2000; Picard and Auwerx, 2002). These observations suggest that bitter gourd may exert its anticancer and antidiabetic activities through similar mechanisms. This hypothesis further gains strength from the reported modulation of apoB secretion and triglyceride synthesis in HepG2 cells (Nerurkar et al., 2005) and amelioration of hyperlipidemia (Senanayake et al., 2004). Furthermore, the emerging evidence suggests that many of the diseases influenced by the bitter gourd such as diabetes, cancer, inflammation, and obesity may have common roots (Masur et al., 2008). Altogether, these observations suggest a central modulatory activity of bitter gourd. However, lack of conclusive evidence seems to keep consumers in the dark and leads to continuation of debate.

In addition to its effect on human diseases, the extracts from different plant parts of bitter gourd were also demonstrated to possess antimicrobial activities, in particular against intestinal pathogens (Omoregbe et al., 1996) as well as antiviral activity (Bourinbaiar and LeeHuang, 1996; Lee-Huang et al., 1995). Another important bioactivity demonstrated by several studies is the abortifacient properties by Momordica proteins. Momorcharins, basic glycoproteins from the bitter gourd, showed abortifacient activity (Chan et al., 1984, 1986; Ng et al., 1992). However, scientific evidence is not sufficient to recommend the use of bitter gourd glycoprotein in pregnancy. More research is required to establish its safe use.

Several bioactive compounds (Fig. 1) were reported from the bitter gourd (Chena et al., 2005; Parkash et al., 2008). Although charantin, vicine, and polypeptide-p are suggested as the main hypoglycemic components (Yeh et al., 2003), the majority of the studies have used crude extracts to demonstrate the hypo-/ antihyperglycemic activity. Furthermore, carotenoids, alkaloids, saponins, and triterpenoids were reported from the bitter gourd (Chen et al., 2008). Carotenoids such as $\beta$-carotene, 
Table 1. Clinical trials of bitter gourd.

\begin{tabular}{lcc}
\hline Trial & Outcome & Reference \\
\hline $\begin{array}{l}\text { Controlled clinical trial } \\
\text { with polypeptide-p } \\
\begin{array}{c}\text { Administration of fruit juice to } \\
\text { maturity-onset diabetic patients }\end{array}\end{array}$ & $\begin{array}{c}\text { Decrease in glucose levels in } \\
\text { glucose tolerance test and HbA1c }\end{array}$ & Welihinda et al., 1986 \\
Aqueous extract of fruit & $\begin{array}{c}\text { Reduction in mean blood and } \\
\text { serum glucose and HbAlc levels }\end{array}$ & Srivastava et al., 1993 \\
Aqueous extract of fruit & $\begin{array}{c}\text { Reduction in fasting and } \\
\text { postprandial serum glucose }\end{array}$ & Ahmad et al., 1999 \\
Bitter gourd capsules & Non-significant reduction in HbA1C & Dans et al., 2007 \\
\hline
\end{tabular}

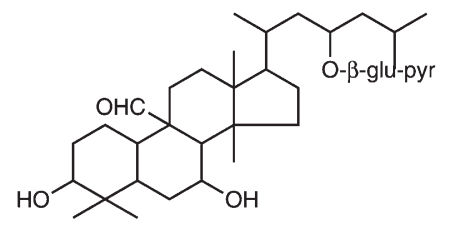

(A)<smiles>C=C(C)C(CC)CCC(C)C1CCC2C1CCC1C2CC=C2CC(O)CCC21C1CCCCC1</smiles>

(C)<smiles>CC1=C(/C=C/C=C/C(C)=C/C=C/C=C(C)/C=C/C=C(C)/C=C/C=C(C)/C=C/C2=C(C)CCCC2(C)C)C(C)(C)CCC1</smiles>

(F)<smiles>CC1=CCCC(C)(C)C1/C=C/C(C)=C/C=C/C(C)=C/C=C/C=C(C)/C=C/C=C(C)/C=C/C1=C(C)CC(O)CC1(C)C</smiles>

(G)<smiles>CC1=C(/C=C/C(C)=C/C=C/C(C)=C/C=C/C(C)=C/C(C)=C/C=C/C(C)=C/C2=C(C)C(O)CC2(C)C)C(C)(C)CC(O)C1</smiles><smiles>CC1=CC(O)CC(C)(C)C1/C=C/C(C)=C/C=C(C)/C=C/C=C(C)/C=C/C=C(C)/C=C/C=C(C)/C=C(C)/C=C(C)/C=C/C1=C(C)CC(O)CC1(C)C</smiles>

Fig. 1. Bioactive compounds of bitter melon (A) momordicin, (B) Kuguacin, (C) charantin, (D) vicine, (E) 5-hydroxytryptamine, (F) $\beta$-carotene, (G) cryptoxanthin, (H) zeaxanthin, (I) lutein.

lutein, and zeaxanthin and their potential health benefits were well documented (Pryor et al., 2000). Momordicin, a triterpenoid, is reported to possess insulin-like activity (Saxena and Vikram, 2004). It is noteworthy that triterpenoids such as limonoids from citrus were reported to demonstrate anticancer activity (Jayaprakasha et al., 2008; Patil et al., 2009; Poulose et al., 2005; Vanamala et al., 2006). It is possible that momordicin may also possess anticancer activity. Identification of the principal bioactive components and mechanisms responsible for their effect on glycemic control and anticancer activity is a major challenge. Elucidation of such components may lead to a better understanding about their incorporation in the diet and chronic disease prevention. Moreover, identification of bioactive compounds will help in understanding molecular mechanisms, which will eventually lead to better appreciation of the indigenous vegetables and fruits. Although several investigations have enumerated the health-promoting properties of bitter gourd, very few studies have demonstrated the underlying mechanism responsible by the specific bioactive compounds. Elucidation of the mode of action of principal components will lead to a better understanding of their role in disease prevention.

\section{OTHER CUCURBITS}

A large variety of cucurbits are consumed as fresh and cooked vegetables throughout the world. Certain cucurbits are cultivated throughout the globe; however, a few are prevalent in Asian and African subcontinent. These include snake gourd, ridge gourd, fuzzy gourd, sponge gourd, and bottle gourd. Ridge gourd (Luffa acutangula $\mathrm{L}$.) is commonly grown in hot, humid tropical areas in Asia. Plants are generally grown on a trellis. Immature fruits, which are dark green with tender ridges, are used in soups and curries or as a cooked vegetable. Ridge gourd seeds contain ribosome-inactivating peptide luffangulin (Wang and Ng, 2002). Another ribosome-inactivating peptide has been isolated from Snake gourd (Chow et al., 1999). In addition, antiviral and hepatoprotective activities were also documented for Snake gourd (Trichosanthes anguina (L.) Haines.) (Chow et al., 1999). However, a detailed investigation about the phytochemical profile and health benefits is still lacking. A particular isoflavone glycoside (Fig. 2), 5,6,6' trimethoxy-3' $4^{\prime}$-methylenedioxyisoflavone 7-O- $\beta$-(2" - O-p-coumaroylglucopyranoside) and Kaempferol-3-O-sophoroside were reported from Snake gourd. The reported isoflavone glycoside (Fig. 2A) is structurally very interesting due to presence of several methoxyl groups because addition of methoxyl groups is speculated to increase the potency in various assays. For example, polymethoxy flavonoids (Raman et al., 2005) and addition of the methoxyl group in citrus limonoids were reported to enhance the potency in anticancer and biofilm assays (Perez et al., 2009; Vikram et al., 2012).

\section{FENUGREEK}

Fenugreek (Trigonella foenum graecum) is a native of Southeastern and West Asia and widely grown in India, Argentina, Egypt, and Mediterranean countries. It is commonly used as a condiment and leafy vegetable as well as widely used in the traditional system of medicine in India. Fenugreek leaves are a rich source of calcium, iron, $\beta$-carotene, and vita$\min \mathrm{K}$. In addition, fenugreek leaves and seeds exhibit hypoglycemic (Abdel-Barry et al., 1997; Vijayakumar et al., 2005) and antihyperglycemic effects in rats (Devi et al., 2003). A few of the case studies related to consumption of fenugreek on diabetes and obesity are presented in Table 2. Consumption of fenugreek seeds was reported to reduce the oxidative stress (Annida and Prince, 2005). Antihyperglycemic activity by fenugreek seems to stem from its ability to modulate GLUT4 and IRS$\beta$, which subsequently resulted in activation of insulin signaling pathways (Vijayakumar et al., 2005). In addition to the effect on blood glucose and corresponding markers, fenugreek was demonstrated to lower the levels of total serum cholesterol, triglycerides, lowdensity lipoprotein, and very low-density lipoprotein in human volunteers without affecting high-density lipoprotein levels (Prasanna, 2000; Sowmya and Rajyalakshmi, 1999).

Protodioscin, trigoneoside, and diosgenin (Fig. 3) are the major bioactive compounds isolated from fenugreek seeds (Murakami et al., 2000; Yoshikawa et al., 1997). Protodioscin and diosgenin possess anticancer activity (Hibasami et al., 2003; Raju et al., 2004). The literature indicates that diosgenin acts on the cell cycle and induces apoptosis 


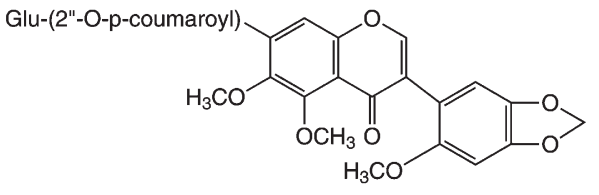

(A)

Fig. 2. Bioactive compounds of Snake gourd (A) 5,6,6'-trimethoxy-3',4'-methylenedioxyisoflavone 7-O$\beta$ - -(2" -O-p-coumaroylglucopyranoside), (B) Kaempferol 3-O-sophoroside.

Table 2. Case studies of fenugreek research.

\begin{tabular}{|c|c|c|}
\hline Study & Outcome & Reference \\
\hline $\begin{array}{l}\text { Case-control study with } 18 \text { subjects } \\
\text { fed fenugreek fiber product }\end{array}$ & $\begin{array}{l}\text { Increase in fullness, satiety } \\
\text { simultaneous decrease } \\
\text { in hunger }\end{array}$ & Mathern et al., 2009 \\
\hline $\begin{array}{l}\text { Case-control study in insulin-dependent } \\
\text { diabetic patients fed fenugreek seed powder }\end{array}$ & $\begin{array}{l}\text { Significant reduction in } \\
\text { fasting blood sugar }\end{array}$ & Sharma et al., 1990 \\
\hline $\begin{array}{l}\text { Case-control study in non insulin-dependent } \\
\text { diabetic patients fed fenugreek seed powder }\end{array}$ & $\begin{array}{l}\text { Significant reduction in } \\
\text { postprandial blood glucose }\end{array}$ & Madar et al., 1988 \\
\hline
\end{tabular}<smiles>CC(CCC1(O)OC2CC3C4CCC5CC(OC6OC(COC7OCC(O)C(O)C7O)C(O)C(O)C6O)C(O)C(C)C5CC4(C)C3CCC21C)COC1OC(CO)C(O)C(O)C1O</smiles>

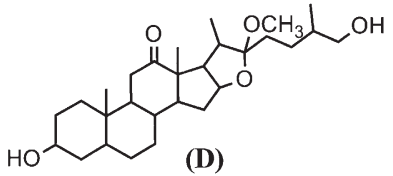

(D)

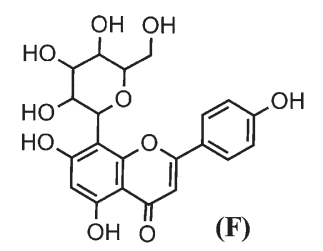

(F)

Fig. 3. Bioactive compounds of fenugreek, (A) Trigoneoside, (B) Diosgenin, (C) Protodiosgenin, (D) Tigogenin, (E) Caffeic acid, (F) Vitexin, (G) Orientin.

(Leger et al., 2004; Liagre et al., 2005). Although few compounds affecting apoptosis in cancerous cell line were enumerated, the compounds imparting hypoglycemic and hypocholesterolemic properties to fenugreek are yet to be identified. Furthermore, isolation and identification of other bioactive compounds, which may have anticarcinogenic properties, is warranted.

\section{DRUMSTICK}

Drumstick (Moringa oleifera Lam.) is native to India, Arabia, and possibly Africa and the East Indies. It is widely cultivated and naturalized in tropical Africa, tropical America, Sri Lanka, India, Mexico, Malabar, Malaysia, and the Philippine Islands. Drumstick plant extract is used in Bangladesh folk medicine as anticancer agents (Costa-Lotufo et al., 2005) and in the treatment of female reproductive disorders (Bose, 2007).

Drumstick leaves are a rich source of $\beta$-carotene, protein, vitamin $\mathrm{C}$, calcium, and potassium as well as of natural antioxidants

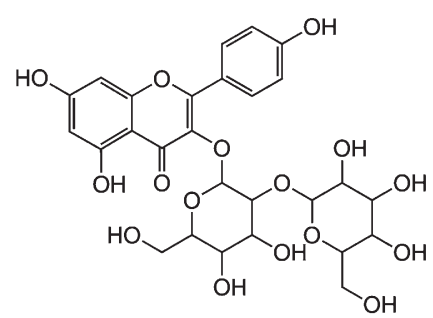

(B)<smiles>CC1COC2(CO1)OC1CC3C4C=C5CC(O)CCC5(C)C4CCC3C1C2C</smiles>

(B)

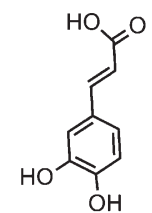

(C)

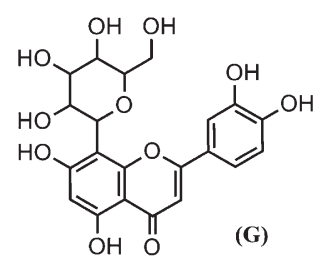

(G) role in the overall blood pressure-lowering effect. Furthermore, cholesterol-lowering properties of drumstick fruit and leaves were demonstrated (Ghasi et al., 2000; Mehta et al., 2003). In addition, antispasmodic activity of the roots and leaves of the drumstick plant was attributed to the presence of thiocarbamates (Dangi et al., 2002; Gilani et al., 1994). Furthermore, leaf and flower extracts were found to be antiulcerogenic and hepatoprotective (Nadro et al., 2006).

Several reports have documented the antimicrobial activities of root, leaf, flower, and bark extracts, which was attributed to the presence of 4- $\alpha$-L-rhamnosyloxy benzyl isothiocyanate, aglycone of deoxy-niazimicine and a peptide (Nikkon et al., 2003; Suarez et al., 2005). Drumstick was also reported to exhibit other diverse activities (reviewed in Anwar et al., 2007). One of the most important bioactivity of drumstick, reported in the literature, was against different types of tumors and cancers. Drumstick leaves were found to be a potential source for antitumor activity. Several compounds isolated from drumstick such as $O$-ethyl-4-( $\alpha$-L-rhamnosyloxy) benzyl carbamate, $4(\alpha-L$-rhamnosyloxy)benzyl isothiocyanate, niazimicin, and 3 - $O$ - $\left(6^{\prime}\right.$ - $O$-oleoyl- $\beta$-D-glucopyranosyl $)-\beta$ sitosterol showed significant inhibitory effects on Epstein-Barr virus early antigen (Murakami et al., 1998). On the other hand, niazimicin was proposed as a potent chemopreventive agent for chemical carcinogenesis (Guevara et al., 1999). Although numerous studies were conducted using different parts of drumstick, very little information is available related to isolation and identification of new compounds from different parts of the tree. Although preliminary studies are underway in different laboratories to determine the potential of drumstick seed as antispasmodic, antiinflammatory, antihypertensive, and diuretic activities, it will be prudent to include the scope of these studies to understand the in vivo effect of various bioactive compounds and their mode of action.

\section{AMARANTH}

Secker, 2003). A unique group of compounds, glucosinolates, and isothiocyanates (Figs. 4C and 4E-J) were reported from the drumstick plant (Bennett et al., 2003; Fahey et al., 2001). In addition, a rich diversity of other secondary metabolites such as moringine and moringinine, vanillin, $\beta$-sitosterol, $\beta$-sitostenone, 4-hydroxymellin and octacosanoic acid, flavonoids kaempherol, rhamnetin, isoquercitrin, and kaempferitrin (Faizi et al., 1994) were reported from drumstick.

Several bioactivities including antiinflammatory, hypocholesterolemic, and hypoglycemic were documented for drumstick preparations (Dangi et al., 2002). The antihypertensive property of drumstick was attributed to nitrile, mustard oil glycosides, and thiocarbamate glycosides (Fig. 4F-J) (Faizi et al., 1998). Drumstick roots, leaves, flowers, gum, and the aqueous infusion of seeds were demonstrated to possess diuretic activity (Caceres et al., 1992) and such diuretic components are likely to play a complementary
Amaranth is one of the few cultivated plants used both as a vegetable and cereal. Amaranth is also cultivated for their ornamental and forage value. Several species, notably Amaranthus tricolor and A. dubius, are commonly grown as leafy vegetables in Eastern Asia, whereas A. cruentus is cultivated in West Africa. Amaranthus cruentus, A. hypochondriacus, and $A$. caudatus are pale-seeded cultivated varieties developed in pre-Columbian times for their edible grain; these continue to be grown on a small scale in Mexico, Central America, and parts of South America (Harley and Ehleringer, 1987). Amaranth is rich in antioxidants (Kelawala and Ananthanarayan, 2004), $\beta$-sitosterol, and other phytosterols (Marcone et al., 2003). Several studies have documented the cholesterol-lowering property of different species of amaranth (Berger et al., 2003; Czerwinski et al., 2004) in animal models. It needs to be emphasized that most 
of the studies related to health-promoting properties were conducted on amaranth grains, which is normally used as cereal. Therefore, different processing products such as extruded amaranth were used in previous studies to understand the health-promoting properties. Research is required to establish the correlation between the bioactive compounds present in the leaves and the health-promoting properties.

Amaranth seems to provide gastroprotection against absolute ethanol (Zayachkivska et al., 2005). Trypsin-chymotrypsin inhibitor protein isolated from amaranth was found to inhibit the anchorage-independent growth of MCF-7 breast cancer cells (Tamir et al., 1996). Amaranthin, a lectin, isolated from the seeds of Amaranthus caudatus was used as a detection tool in colon cancer diagnosis (Tetsutaro and Jürgen, 1994). A few major secondary metabolites of Amaranthus spp. are presented in Fig. 5. However, further research is needed to establish the effect of these compounds on human health by conducting cohort and randomized controlled human clinical trials.

\section{CLUSTER BEAN (CYAMOPSIS TETRAGONOLOBA L.)}

Cluster bean (Cyamopsis tetragonoloba L.) is a native of the Indian subcontinent and widely distributed across Africa and Asia. The cluster bean is being cultivated in smaller area of certain states in the United States and Australia. The immature pods of cluster bean are used as a vegetable in India. The seeds are source of guar-gum, a galactomannan storage polysaccharide, which was reported to help in irritable bowl syndrome and reduction in serum cholesterol and diabetes as well as used for targeted delivery of drugs to the colon (Jenkins et al., 1979). In a study, conducted with 25 non-obese volunteers, guar-gum increased the effect of insulin, lowered the glucose and lipid concentrations as well as plasminogen activator inhibitor-1 activity and blood pressure without affecting body weight (Landin et al., 1992). Another study reported a significant reduction in fasting blood glucose and serum total cholesterol over a 3-month period by guar-gum consumption. However, the metabolic conditions of patients with diabetes did not improve in the same study (Uusitupa et al., 1989). Furthermore, a guar-gum-based diet was reported to reduce total and low-density lipoprotein cholesterol levels (Khan et al., 1981). Another line of evidence indicates that guar-gum may be beneficial for reducing body weight. It was suggested that guar-gum increases the viscosity of the bowel content and the feeling of postprandial fullness, which in turn may reduce appetite and food intake (Blackburn et al., 1984; Tuomilehto et al., 1989). In addition, guar-gum was suggested to exert an action on glucose absorption by impairing diffusion rate (Lembcke et al., 1984), which may lead to a prolonged period of glucose uptake in the intestine and consequently a prolonged influence on blood glucose and possibly on insulin levels. These results, along with the fact that<smiles>O=c1c(O)c(-c2ccc(O)c(O)c2)oc2cc(O)cc(O)c12</smiles>

(A)<smiles>O=C(/C=C/c1ccc(O)c(O)c1)OC1CC(O)(C(=O)O)CC(O)C1O</smiles>

(D)<smiles>CCOC(=S)NCCc1ccc(OC2OC3COC(O)C(O3)O2)cc1</smiles>
$\mathrm{HO}$ त्र

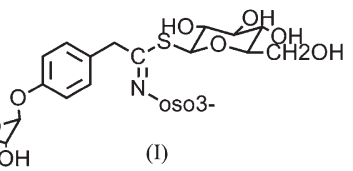

Fig. 4. Bioactive compounds of Drumstick (A) quercetin, (B) kaempferol, (C) moringine, (D) chlorogenic acid, (E) benzylisothiocyanate, (F) niazimicin, (G) $4(\alpha$-L-rhamnosyloxy) benzyl isothiocyanate, $(\mathbf{H})$ 4(4'-Oacetyl- $\alpha$-L-rhamnopyranosyloxy) benzyl isothiocyanate, (I) 4( $\alpha$-L-rhamnosyloxy)benzyl isothiocyanate, (J) Pterygospermin.

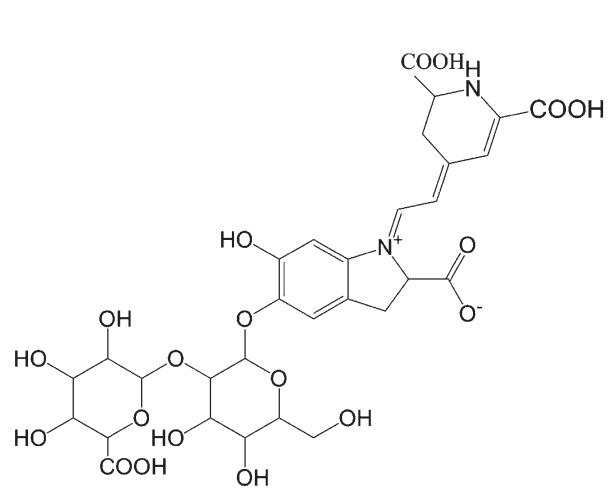<smiles>Cc1cc2nc3c(=O)[nH]c(=O)nc-3n(CC(O)C(O)C(O)CO)c2cc1C</smiles>

(A)<smiles>Oc1cc(O)c2c(c1)OC(c1ccc(O)c(O)c1)C(O)C2</smiles>

(C)<smiles>O=c1c(O)c(-c2ccc(O)cc2)oc2cc(O)cc(O)c12</smiles>

(B)
(C)<smiles>CN(C)Cc1ccccc1</smiles>

(F)<smiles>NCc1ccccc1</smiles><smiles>CC(=O)OC1CC2OC(C1)C(O)C(Oc1ccc(CNS(C)(=O)=O)cc1)O2</smiles><smiles>S=C1NOC23CC2(C=CC12ON(Cc1ccccc1)C2=S)ONC3=S</smiles>

(J)

Fig. 5. Bioactive compounds of Amaranthus spp. (A) Amaranthine, (B) Riboflavin, (C) Catechin, (D) Procyanidin.

other nutrients may be absorbed at a lower rate, may affect satiety. Although accumulating evidence suggests that guar-gum consumption may be beneficial, studies related to specific bioactive compounds and their structure-function relationship needs to be carried out to fully understand their mechanism of action. It is very important that both positive and negative effects of these vegetables need to be understood. Further 
Table 3. Proximate and nutrient compositions of selected crops indigenous to Asia and Southeast Asia.

\begin{tabular}{|c|c|c|c|c|c|}
\hline & & $\begin{array}{l}\text { Amaranth } \\
\text { leaves }\end{array}$ & $\begin{array}{l}\text { Bitter } \\
\text { melon }\end{array}$ & $\begin{array}{c}\text { Fenugreek } \\
\text { seeds }\end{array}$ & $\begin{array}{c}\text { Drumstick } \\
\text { leaves }\end{array}$ \\
\hline \multicolumn{6}{|c|}{ Proximates (per $100 \mathrm{~g}$ fresh $\mathrm{wt}$ ) } \\
\hline Water & $\mathrm{G}$ & 91.69 & 94.03 & 8.84 & 78.66 \\
\hline Energy & Kcal & 23 & 17 & 323 & 64 \\
\hline Protein & G & 2.46 & 1 & 23 & 9.4 \\
\hline Total lipid (fat) & G & 0.33 & 0.17 & 6.41 & 1.4 \\
\hline $\begin{array}{c}\text { Carbohydrate, } \\
\text { by difference }\end{array}$ & G & 4.02 & 3.7 & 58.35 & 8.28 \\
\hline Fiber, total dietary & & & 2.8 & 24.6 & 2 \\
\hline \multicolumn{6}{|c|}{ Minerals (per $100 \mathrm{~g}$ fresh wt) } \\
\hline Calcium & $\mathrm{mg}$ & 215 & 19 & 176 & 185 \\
\hline Iron & $\mathrm{mg}$ & 2.32 & 0.43 & 33.53 & 4 \\
\hline Magnesium & $\mathrm{mg}$ & 55 & 17 & 191 & 147 \\
\hline Phosphorus & $\mathrm{mg}$ & 50 & 31 & 296 & 112 \\
\hline Potassium & $\mathrm{mg}$ & 611 & 296 & 770 & 337 \\
\hline Sodium & $\mathrm{mg}$ & 20 & 5 & 67 & 9 \\
\hline Zinc & $\mathrm{mg}$ & 0.9 & 0.8 & 2.5 & 0.6 \\
\hline
\end{tabular}

Source: USDA Nutrient Database (USDA-ARS, 2011).

research needs to determine toxicity of the guar-gum before reaching any conclusions about its potential benefits of risk reduction of certain diseases.

\section{KANGKONG}

Kangkong (Ipomoea aquatica Forsk), also known as Swamp Cabbage or Water Convolvulus, is widely cultivated throughout the world; however, it is regarded as an important leafy crop only in South and Southeast Asia. Kangkong is a very rich source of $\beta$-carotene, riboflavin, and ascorbic acid (Ismail and Fun, 2003). In addition, kangkong is reported to be a good source of total phenolics and consequently has a high total antioxidant activity (Ismail et al., 2004).

Kangkong is a good source of $\beta$-carotene with good bioavailability. In a feeding trial of rats, conversion of $\beta$-carotene to liver retinol for the first 2 weeks was efficient (Tee et al., 1996). However, poor conversion of $\beta$ carotene to retinol after 2 weeks was observed. This loss in conversion of $\beta$-carotene to retinol was attributed to the poor conversion and incomplete consumption of the all the vegetables as a result of poor acceptance by the animals. Lutein, another carotenoid found in kangkong, was present in high concentrations in the liver of the rats fed with a kangkong diet. In another study, kangkong was found to reduce the absorption of the cholesterol by increasing the fecal excretion (Chen et al., 1984).

Kangkong is an important constituent of the South and Southeast Asian diet. However, the nutritional composition of kangkong was not elucidated until now, suggesting an opportunity for investigation of different components of this important vegetable. Furthermore, exploration of human health properties by isolating and identifying the specific bioactive compounds is required. Although one study demonstrated lower absorption of cholesterol in rats, more detailed studies are critical to establish the "proof of the concept" of kangkong's potential in reducing cholesterol. Moreover, the effect of kangkong on different biological activities, which eventually affect human health, needs to be investigated.
Ahmed, I., E. Adeghate, E. Cummings, A.K Sharma, and J. Singh. 2004. Beneficial effects and mechanism of action of Momordica charantia juice in the treatment of streptozotocininduced diabetes mellitus in rat. Mol. Cell. Biochem. 261:63-70.

Annida, B. and P.S.M. Prince. 2005. Supplementation of fenugreek leaves reduces oxidative stress in streptozotocin-induced diabetic rats. J. Med. Food 8:382-385.

Anwar, F., S. Latif, M. Ashraf, and A.H. Gilani. 2007. Moringa oleifera: A food plant with multiple medicinal uses. Phytother. Res. 21:17-25.

Baldwa, V., C. Bhandari, A. Pangaria, and R. Goyal. 1977. Clinical trial in patients with diabetes mellitus of an insulin-like compound obtained from plant source. Ups. J. Med. Sci. 82:39-41.

Bennett, R.N., F.A. Mellon, N. Foidl, J.H. Pratt, M.S. Dupont, L. Perkins, and P.A. Kroon. 2003. Profiling glucosinolates and phenolics in vegetative and reproductive tissues of the multipurpose trees Moringa oleifera L. (Horseradish tree) and Moringa stenopetala L. J. Agr. Food Chem. 51:3546-3553.

Indigenous vegetables are considered an important part of the diet in Asia and Southeast Asia. However, in recent times, FAVs are being replaced by more convenient foods. This trend also correlates with an increased incidence of chronic diseases such as cancer and cardiovascular diseases. Literature suggests that these indigenous vegetables may contain certain health beneficial properties. In addition, these vegetables are excellent sources of various nutrients (Table 3 ). However, their potential for human health benefits has not been explored to the full potential. Therefore, there is an apparent need to evaluate these indigenous crops for their bioactive components and effect on various chronic diseases. Such studies may provide the necessary information to incorporate these vegetables in a dietary regime for prevention or sustenance of health in disease conditions. The incorporation of these crops in the dietary regime may also reduce the healthcare cost. In this review, we have presented the information about only certain indigenous vegetables grown in Southeast Asia, but there are a number of indigenous crops grown and used in different parts of world. These crops should be explored for their potential healthpromoting properties. It is clear that certain indigenous crops play an important role in reducing hunger and providing protection against several deadly diseases. This goal is possible only after conducting more research from "farm to consumer" including randomized clinical trials to provide a complete "proof of concept" of the potential of the indigenous crops.

\section{Literature Cited}

Abdel-Barry, J.A., I.A. Abdel-Hassan, and M.H.H. Al-Hakiem. 1997. Hypoglycaemic and antihyperglycaemic effects of Trigonella foenumgraecum leaf in normal and alloxan induced diabetic rats. J. Ethnopharmacol. 58:149-155.

Ahmad, N., M. Hassan, H. Halder, and K. Bennoor. 1999. Effect of Momordica charantia (Karolla) extracts on fasting and postprandial serum glucose levels in NIDDM patients. Bangladesh Med. Res. Counc. Bull. 25:11.
Berger, A., I. Monnard, F. Dionisi, D. Gumy, K.C. Hayes, and P. Lambelet. 2003. Cholesterollowering properties of amaranth flakes, crude and refined oils in hamsters. Food Chem. 81:119 124.

Blackburn, N., J. Redfern, H. Jarjis, A. Holgate, I. Hanning, J. Scarpello, I. Johnson, and N. Read. 1984. The mechanism of action of guar gum in improving glucose tolerance in man. Clin. Sci. 66:329.

Bose, C. 2007. Possible role of Moringa oleifera Lam. root in epithelial ovarian cancer. Medscape Gen. Med. 9:26.

Bourinbaiar, A.S. and S. Lee-Huang. 1996. The activity of plant-derived antiretroviral proteins MAP30 and GAP31 against herpes simplex virus infection in vitro. Biochem. Biophys. Res. Commun. 219:923-929.

Caceres, A., A. Saravia, S. Rizzo, L. Zabala, E. De Leon, and F. Nave. 1992. Pharmacologic properties of Moringa oleifera. 2: Screening for antispasmodic, antiinflammatory and diuretic activity. J. Ethnopharmacol. 36:233-237.

Chan, W.Y., P.P. Tam, H.L. Choi, T.B. Ng, and H.W. Yeung. 1986. Effects of momorcharins on the mouse embryo at the early organogenesis stage. Contraception 34:537-544. The termination of early pregnancy in the mouse by beta-momorcharin. Contraception 29:91-100.

Che-Yi, C. and H. Ching-jang. 2003. Bitter gourd (Momordica charantia) extract activates peroxisome proliferator-activated receptors and upregulates the expression of the acyl CoA oxidase gene in H4IIEC3 hepatoma cells. J. Biomed. Sci. 10:782-791.

Chen, J., R. Tian, M. Qiu, L. Lu, Y. Zheng, and Z. Zhang. 2008. Trinorcucurbitane and cucurbitane triterpenoids from the roots of Momordica charantia. Phytochemistry 69:1043-1048.

Chen, M.L., D.F. Chia, and J.Q. Run. 1984. Effect of dietary vegetable (water convolvulus) on cholesterol metabolism in rats. J. Nutr. 114:503-510.

Chen, Q., L.L.Y. Chan, and E.T.S. Li. 2003. Bitter melon (Momordica charantia) reduces adiposity, lowers serum insulin and normalizes glucose tolerance in rats fed a high fat diet. J. Nutr. 133:1088-1093

Chena, J.C., M.H. Chiu, R.L. Niea, G.A. Cordellb, and S.X. Qiuc. 2005. Cucurbitacins and cucurbitane glycosides: Structures and biological activities. Nat. Prod. Rep. 22:386-399.
Chan, W.Y., P.P. Tam, and H.W. Yeung. 1984. 
Chow, L.-P., M.-H. Chou, C.-Y.Ho, C.-C. Chuang, F.-M. Pan, S.-H. Wu, and J.-Y. Lin. 1999. Purification, characterization and molecular cloning of trichoanguin, a novel type I ribosome-inactivating protein from the seeds of Trichosanthes anguina. Biochem. J. 338:211219.

Costa-Lotufo, L., M. Khan, A. Ather, D. Wilke, P. Jimenez, C. Pessoa, M. de Moraes, and M. de Moraes. 2005. Studies of the anticancer potential of plants used in Bangladeshi folk medicine. J. Ethnopharmacol. 99:21-30.

Czerwinski, J., E. Bartnikowska, H. Leontowicz, E. Lange, M. Leontowicz, E. Katrich, S. Trakhtenberg, and S. Gorinstein. 2004. Oat (Avena sativa L.) and amaranth (Amaranthus hypochondriacus) meals positively affect plasma lipid profile in rats fed cholesterol-containing diets. J. Nutr. Biochem. 15:622-629.

Dangi, S.Y., C.I. Jolly, and S. Narayanan. 2002. Antihypertensive activity of the total alkaloids from the leaves of Moringa oleifera. Pharm. Biol. 40:144-148.

Dans, A.M.L., M.V.C. Villarruz, C.A. Jimeno, M.A.U. Javelosa, J. Chua, R. Bautista, and G.G.B. Velez. 2007. The effect of Momordica charantia capsule preparation on glycemic control in Type 2 diabetes mellitus needs further studies. J. Clin. Epidemiol. 60:554559.

Devi, B.A., N. Kamalakkannan, and P.S.M. Prince. 2003. Supplementation of fenugreek leaves to diabetic rats. Effect on carbohydrate metabolic enzymes in diabetic liver and kidney. Phytother. Res. 17:1231-1233.

Dillard, C.J. and J.B. German. 2000. Phytochemicals: Nutraceuticals and human health: A review. J. Sci. Food Agr. 80:1744-1756.

Fahey, J.W., A.T. Zalcmann, and P. Talalay. 2001. The chemical diversity and distribution of glucosinolates and isothiocyanates among plants. Phytochemistry 56:5-51.

Faizi, S., B.S. Siddiqui, R. Saleem, K. Aftab, F. Shaheen, and A.H. Gilani. 1998. Hypotensive constituents from the pods of Moringa oleifera. Planta Med. 64:225-228.

Faizi, S., B.S. Siddiqui, R. Saleem, S. Siddiqui, K. Aftab, and A.-U.H. Gilani. 1994. Isolation and structure elucidation of new nitrile and mustard oil glycosides from Moringa oleifera and their effect on blood pressure. J. Nat. Prod. 57:12561261.

Ghasi, S., E. Nwobodo, and J.O. Ofili. 2000. Hypocholesterolemic effects of crude extract of leaf of Moringa oleifera Lam in high-fat diet fed Wistar rats. J. Ethnopharmacol. 69:21-25.

Gilani, A.H., K. Aftab, A. Suria, S. Siddiqui, R. Salem, B.S. Siddiqui, and S. Faizi. 1994. Pharmacological studies on hypotensive and spasmolytic activities of pure compounds from Moringa oleifera. Phytother. Res. 8:87-91.

Grover, J.K. and S.P. Yadav. 2004. Pharmacological actions and potential uses of Momordica charantia: A review. J. Ethnopharmacol. 93:123132.

Guevara, A.P., C. Vargas, H. Sakurai, Y. Fujiwara, K. Hashimoto, T. Maoka, M. Kozuka, Y. Ito, H. Tokuda, and H. Nishino. 1999. An antitumor promoter from Moringa oleifera Lam. Mutat. Res. 440:181-188.

Harley, P.C. and J. Ehleringer. 1987. Gas exchange characteristics of leaves of four species of grain amaranth. Field Crops Res. 17:141-153.

Hibasami, H., H. Moteki, K. Ishikawa, H. Katsuzaki, K. Imai, Y. Ishii, and T. Komiya. 2003. Protodioscin isolated from fenugreek (Trigonella foenumgraecum L.) induces cell death and morphological change indicative of apoptosis in leulemic cell line H-60, but not in gastric cancer cell line KATO III. Intl. J. Mol. Med. $11: 23-26$.

Ismail, A. and C.S. Fun. 2003. Determination of vitamin $C, \beta$-carotene and riboflavin contents in five green vegetables organically and conventionally grown. Mal. J. Nutr. 9:31-39.

Ismail, A., Z.M. Marjan, and C.W. Foong. 2004 Total antioxidant activity and phenolic content in selected vegetables. Food Chem. 87:581586.

Jayaprakasha, G.K., K.K. Mandadi, S.M. Poulose, Y. Jadegoud, G.A. Nagana Gowda, and B.S. Patil. 2008. Novel triterpenoid from Citrus aurantium L. possesses chemopreventive properties against human colon cancer cells. Bioorg. Med. Chem. 16:5939-5951.

Jenkins, D.J., A.R. Leeds, B. Slavin, J. Mann, and E.M. Jepson. 1979. Dietary fiber and blood lipids: Reduction of serum cholesterol in type II hyperlipidemia by guar gum. Amer. J. Clin. Nutr. 32:16-18.

Kelawala and, and Ananthanarayan. 2004. Antioxidant activity of selected foodstuffs. Intl. J. Food Sci. Nutr. 55:511-516.

Kersten, S., B. Desvergne, and W. Wahli. 2000. Roles of PPARs in health and disease. Nature 405:421-424.

Khan, A.R., G.Y. Khan, A. Mitchel, and M.A. Qadeer. 1981. Effect of guar gum on blood lipids. Amer. J. Clin. Nutr. 34:2446-2449.

Kobori, M. 2003. In vitro-screening for cancersuppressive effect of food components. Jpn. Agr. Res. Q. 37:159-166.

Landin, K., G. Holm, L. Tengborn, and U. Smith. 1992. Guar gum improves insulin sensitivity, blood lipids, blood pressure, and fibrinolysis in healthy men. Amer. J. Clin. Nutr. 56:10611065.

Lee-Huang, S., P.L. Huang, P.L. Huang, A.S. Bourinbaiar, H. Chen, and H. Kung. 1995. Inhibition of the integrase of human immunodeficiency virus (HIV) type 1 by anti-HIV plant proteins MAP30 and GAP31. Proc. Natl. Acad. Sci. USA 92:8818-8822.

Leger, D.Y., B. Liagre, C. Corbiere, J. CookMoreau, and J.L. Beneytout. 2004. Diosgenin induces cell cycle arrest and apoptosis in HEL cells with increase in intracellular calcium level, activation of $\mathrm{cPLA}_{2}$ and $\mathrm{COX}-2$ overexpression. Int. J. Oncol. 22:555-562.

Lembcke, B., R. Ebert, M. Ptok, W.F. Caspary, W Creutzfeld, H. Schicha, and D. Emrich. 1984. Role of gastrointestinal transit in the delay of absorption by viscous fibre (guar). Hepatogastroenterology 31:183-186.

Liagre, B., J. Bertrand, D.Y. Leger, and J.-L. Beneytout. 2005. Diosgenin, a plant steroid, induces apoptosis in COX-2 deficient K562 cells with activation of the p38 MAP kinase signalling and inhibition of NF- $\mathrm{\kappa B}$ binding. Intl. J. Mol. Med. 16:1095-1101.

Madar, Z., R. Abel, S. Samish, and J. Arad. 1988. Glucose-lowering effect of fenugreek in noninsulin dependent diabetics. Eur. J. Clin. Nutr. 42:51.

Marcone, M.F., Y. Kakuda, and R.Y. Yada. 2003. Amaranth as a rich dietary source of $\beta$-sitosterol and other phytosterols. Plant Foods Hum. Nutr. V58:207-211.

Masur, K., F. Thévenod, and K. Zänker. 2008. Diabetes and cancer: Epidemiological evidence and molecular links. In: Porta, M. and F.M. Matschinsky (eds.). Frontiers in diabetes. Karger, Basel, Switzerland.

Mathern, J.R., S.K. Raatz, W. Thomas, and J.L. Slavin. 2009. Effect of fenugreek fiber on satiety, blood glucose and insulin response and energy intake in obese subjects. Phytother. Res. 23:1543-1548.

Mehta, K., R. Balaraman, A.H. Amin, P.A. Bafna, and O.D. Gulati. 2003. Effect of fruits of Moringa oleifera on the lipid profile of normal and hypercholesterolaemic rabbits. J. Ethnopharmacol. 86:191-195.

Murakami, A., Y. Kitazono, S. Jiwajinda, K. Koshimizu, and H. Ohigashi. 1998. Niaziminin, a thiocarbamate from the leaves of Moringa oleifera, holds a strict structural requirement for inhibition of tumor-promoter-induced EpsteinBarr virus activation. Planta Med. 64:319323.

Murakami, T., A. Kishi, H. Matsuda, and M. Yoshikawa. 2000. Medicinal foodstuffs. XVII. Fenugreek seed (3): Structures of new furastanol type steroid saponins, trigoneosides $\mathrm{Xa}, \mathrm{Xb}$, XIb, XIIa, XIIb and XIIIa, from the seeds of egyptian Trigonella foenum graceum L. Chem. Pharm. Bull. (Tokyo) 48:994-1000.

Nadro, M.S., R.M. Arungbemi, and D. Dahiru. 2006. Evaluation of Moringa oleifera leaf extract on alcohol-induced hepatotoxicity. Trop. J. Pharm. Res. 5:539-544.

Nerurkar, P.V., L. Pearson, J.T. Efird, K. Adeli, A.G. Theriault, and V.R. Nerurkar. 2005. Microsomal triglyceride transfer protein gene expression and $\mathrm{ApoB}$ secretion are inhibited by bitter melon in HepG2 cells. J. Nutr. 135:702706.

Ng, T.B., W.Y. Chan, and H.W. Yeung. 1992. Proteins with abortifacient, ribosome inactivating, immunomodulatory, antitumor and antiAIDS activities from cucurbitaceae plants. Gen. Pharmacol. 23:575-590.

Nikkon, F., Z.A. Saud, M.H. Rahman, and M.E. Haque. 2003. In vitro antimicrobial activity of the compound isolated from chloroform extract of Moringa oleifera Lam. Pak. J. Biol. Sci. 6:1888-1890.

Omoregbe, R.E., O.M. Ikuebe, and I.G. Ihimire. 1996. Antimicrobial activity of some medicinal plants extracts on Escherichia coli, Salmonella paratyphi and Shigella dysenteriae. Afr. J. Med. Med. Sci. 25:373-375.

Parkash, A., T. Ng, and W. Tso. 2008. Purification and characterization of charantin, a napin-like ribosome-inactivating peptide from bitter gourd (Momordica charantia) seeds. J. Pept. Res. 59:197-202.

Patil, B.S., G.K. Jayaprakasha, K.N. Chidambara Murthy, and A. Vikram. 2009. Bioactive compounds: Historical perspectives, opportunities, and challenges. J. Agr. Food Chem. 57:81428160.

Perez, J.L., G.K. Jayaprakasha, V. Valdivia, D. Munoz, D.V. Dandekar, H. Ahmad, and B.S. Patil. 2009. Limonin methoxylation influences the induction of glutathione S-transferase and quinone reductase. J. Agr. Food Chem. 57:52795286.

Picard, F. and J. Auwerx. 2002. PPAR $\gamma$ and glucose homeostasis. Annu. Rev. Nutr. 22: 167-197.

Pierce, J.P., L. Natarajan, B.J. Caan, B.A. Parker, E.R. Greenberg, S.W. Flatt, C.L. Rock, S. Kealey, W.K. Al-Delaimy, W.A. Bardwell, R.W. Carlson, J.A. Emond, S. Faerber, E.B. Gold, R.A. Hajek, K. Hollenbach, L.A. Jones, N. Karanja, L. Madlensky, J. Marshall, V.A. Newman, C. Ritenbaugh, C.A. Thomson, L. Wasserman, and M.L. Stefanick. 2007. Influence of a diet very high in vegetables, fruit, and fiber and low in fat on prognosis following treatment for breast cancer: The Women's Healthy Eating and Living (WHEL) Randomized Trial. JAMA 298:289-298. 
Poulose, S.M., E.D. Harris, and B.S. Patil. 2005. Citrus limonoids induce apoptosis in human neuroblastoma cells and have radical scavenging activity. J. Nutr. 135:870-877.

Prasanna, M. 2000. Hypolipidemic effect of fenugreek: A clinical study. Indian J. Pharm. 32:34 36.

Prohens, J., A. Rodríguez-Burruezo, and F. Nuez. 2003. New crops: An alternative for the development of horticulture. J. Food Agr. Environ. 1:75-79.

Pryor, W.A., W. Stahl, and C.L. Rock. 2000. Beta carotene: From biochemistry to clinical trials. Nutr. Rev. 58:39-53.

Raju, J., J.M.R. Patlolla, M.V. Swamy, and C.V. Rao. 2004. Diosgenin, a steroid saponin of Trigonella foenum graecum (Fenugreek), inhibits azoxymethane-induced aberrant crypt foci formation in F344 rats and induces apoptosis in HT-29 human colon cancer cells. Cancer Epidemiol. Biomarkers Prev. 13:13921398.

Raman, G., G.K. Jayaprakasha, M. Cho, J. Brodbelt, and B.S. Patil. 2005. Rapid adsorptive separation of citrus polymethoxylated flavones in nonaqueous conditions. Separ. Purif. Tech. 45:147152.

Raza, H., I. Ahmed, A. John, and A.K. Sharma. 2000. Modulation of xenobiotic metabolism and oxidative stress in chronic streptozotocininduced diabetic rats fed with Momordica charantia fruit extract. Biochem. Mol. Toxico. 14:131-139.

Sarkar, S., M. Pranava, and M. Rosalind. 1996. Demonstration of the hypoglycemic action of Momordica charantia in a validated animal model of diabetes. Pharmacol. Res. 33:1-4.

Saxena, A. and N. Vikram. 2004. Role of selected Indian plants in management of type 2 diabetes: A review. J. Alternative Comp. Med. 10:369-378.

Senanayake, G.V., M. Maruyama, M. Sakono, N. Fukuda, T. Morishita, C. Yukizaki, M. Kawano, and H. Ohta. 2004. The effects of bitter melon (Momordica charantia) extracts on serum and liver lipid parameters in hamsters fed cholesterolfree and cholesterol-enriched diets. J. Nutr. Sci. Vitaminol. (Tokyo) 50:253-257.

Sharma, R., T. Raghuram, and N. Rao. 1990. Effect of fenugreek seeds on blood glucose and serum lipids in type I diabetes. Eur. J. Clin. Nutr. 44:301.

Siddhuraju, P. and K. Becker. 2003. Antioxidant properties of various solvent extracts of total phenolic constituents from three different agroclimatic origins of drumstick tree (Moringa oleifera Lam.) leaves. J. Agr. Food Chem. 51:2144-2155.

Sowmya, P. and P. Rajyalakshmi. 1999. Hypocholesterolemic effect of germinated fenugreek seeds in human subjects. Plant Foods Hum. Nutr. 53:359-365.

Srivastava, Y., H. Venkatakrishna-Bhatt, Y. Verma, K. Venkaiah, and B. Raval. 1993. Antidiabetic and adaptogenic properties of Momordica charantia extract: An experimental and clinical evaluation. Phytother. Res. 7:285.

Suarez, M., M. Haenni, S. Canarelli, F. Fisch, P. Chodanowski, C. Servis, O. Michielin, R. Freitag, P. Moreillon, and N. Mermod. 2005. Structurefunction characterization and optimization of a plant-derived antibacterial peptide. Antimicrob. Agents Chemother. 49:3847-3857.

Tamir, S., J. Bell, T.H. Finlay, E. Sakal, P. Smirnoff, S. Gaur, and Y. Birk. 1996. Isolation, characterization, and properties of a trypsin-chymotrypsin inhibitor from amaranth seeds. J. Protein Chem. V15:219-229.

Tee, E.S., C.L. Lim, Y.H. Chong, and S.C. Khor. 1996. A study of the biological utilization of carotenoids of carrot and swamp cabbage in rats. Food Chem. 56:21-32.

Tetsutaro, S. and R. Jürgen. 1994. Lectin histochemistry for the study of glycoconjugate residues on colonic adenocarcinoma. Med. Electron Microsc. 27:308-311.

Tuomilehto, J., M. Silvasti, V. Manninen, M. Uusitupa, and A. Aro. 1989. Guar gum and gemfibrozil-An effective combination in the treatment of hypercholesterolaemia. Atherosclerosis 76:71-77.

USDA-ARS. 2011. USDA National Nutrient Database for Standard Reference, Release 24 Nutrient Data Laboratory home page. 26 Apr. 2010. <http://www.ars.usda.gov/nutrientdata>

Uusitupa, M., O. Siitonen, K. Savolainen, M. Silvasti, I. Penttila, and M. Parviainen. 1989. Metabolic and nutritional effects of long-term use of guar gum in the treatment of noninsulindependent diabetes of poor metabolic control. Amer. J. Clin. Nutr. 49:345-351.

van Gils, C.H., P.H.M. Peeters, H.B. Bueno-deMesquita, H.C. Boshuizen, P.H. Lahmann, F. Clavel-Chapelon, A. Thiebaut, E. Kesse, S. Sieri, D. Palli, R. Tumino, S. Panico, P. Vineis, C.A. Gonzalez, E. Ardanaz, M.-J. Sanchez, P. Amiano, C. Navarro, J.R. Quiros, T.J. Key, N. Allen, K.-T Khaw, S.A. Bingham, T. Psaltopoulou, M. Koliva, A. Trichopoulou, G. Nagel, J. Linseisen, H. Boeing, G. Berglund, E. Wirfalt, G. Hallmans, P. Lenner, K. Overvad, A. Tjonneland, A.
Olsen, E. Lund, D. Engeset, E. Alsaker, T. Norat, R. Kaaks, N. Slimani, and E. Riboli. 2005. Consumption of vegetables and fruits and risk of breast cancer. JAMA 293:183193.

Vanamala, J., T. Leonardi, B.S. Patil, S.S. Taddeo, M.E. Murphy, L.M. Pike, R.S. Chapkin, J.R. Lupton, and N.D. Turner. 2006. Suppression of colon carcinogenesis by bioactive compounds in grapefruit. Carcinogenesis 27:1257-1265.

Vietmeyer, N.D. 1986. Lesser-known plants of potential use in agriculture and forestry. Science 232:1379-1384.

Vijayakumar, M.V., S. Singh, R.R. Chhipa, and M.K. Bhat. 2005. The hypoglycaemic activity of fenugreek seed extract is mediated through the stimulation of an insulin signalling pathway. British J. Pharm. 146:41-48.

Vikram, A., G.K. Jayaprakasha, P.R. Jesudhasan, S.D. Pillai, and B.S. Patil. 2012. Limonin $7-$ methoxime interferes with Escherichia coli biofilm formation and attachment in type 1 pili and antigen 43 dependent manner. Food Contr. 26:427-438.

Wang, H. and T.B. Ng. 2002. Luffangulin, a novel ribosome inactivating peptide from ridge gourd (Luffa acutangula) seeds. Life Sci. 70:899906.

Welihinda, J., G. Arvidson, E. Gylfe, B. Hellman, and E. Karlsson. 1982. The insulin-releasing activity of the tropical plant Momordica charantia. Acta Biol. Med. Ger. 41:12291240.

Welihinda, J., E.H. Karunanayake, M.H.H. Sheriff, and K.S.A. Jayasinghe. 1986. Effect of Momordica charantia on the glucose tolerance in maturity onset diabetes. J. Ethnopharmacol. 17:277282 .

Yeh, G., D. Eisenberg, T. Kaptchuk, and R. Phillips. 2003. Systematic review of herbs and dietary supplements for glycemic control in diabetes. Diabetes Care 26:1277.

Yoshikawa, M., T. Murakami, H. Komatsu, N. Murakami, J. Yamahara, and H. Matsuda. 1997. Medicinal foodstuffs. IV. Fenugreek Seed. (1): Structures of trigoneosides Ia, Ib, IIa, IIb, IIIa and IIIb, new furastanol saponins from the seeds of Indian Trigonella foenumgraceum L. Chem. Pharm. Bull. (Tokyo) 45:8187.

Zayachkivska, O.S., S.J. Konturek, D. Drozdowicz, P.C. Konturek, T. Brzozowski, and M.R. Ghegotsky. 2005. Gastroprotective effects of flavonoids in plant extracts. J. Physiol. Pharmacol. 56(suppl. 1):219-231. 